Hamid Rajaei. Retrieved from http://en.wikipedia.org/wiki/Hamid_Rajaei\#Creativity_theory.2C_The_prolixes_and_the_simplifiers.2C_Epistemological_attitude

Il'ina, V. N. (2005). Razvitie lichnosti rebenka ot trekh do pyati [Development of the child's personality from three to five]. Ekaterinburg: U-Faktoriya [in Russian].

Karter, F. (2005). Testy otsenki lichnosti, sklonnostei i intellekta [Tests of personality, inclinations and intelligence assessment]. Sankt-Peterburg: Piter [in Russian].

Kremen, V. H. (Ed.). (2008). Entsyklopediia osvity. Akademiia pedahohichnykh nauk Ukrainy [Encyclopedia of Education. Acad ped Sciences of Ukraine]. Kyiv: Yurinkom Inter [in Ukrainian].

Medina, Dzhon. (2016). Pravyla rozvytku mozku dytyny [Rules for the development of the brain of a child]. Kyiv: Nash format [in Ukrainian].

Rodzhers, K. R. (1994). Vzglyad na psikhoterapiyu. Stanovlenie cheloveka [The View of Psychotherapy. Formation of a person]. Moskva: Progress [in Russian].

The Future of Jobs. Employment, Skills and. Workforce Strategy for the. Fourth Industrial Revolution. Retrieved from http://www3.weforum.org/docs/WEF_Future_of_Jobs.pdf

Vygotskii, L. S. (1991). Voobrazhenie i tvorchestvo v detskom vozraste: Psikhologicheskii ocherk [Imagination and creativity in childhood: Psychological essay]. Moskva: Prosveshchenie [in Russian].

VALENTYNA KRAMARENKO

Place of work: Kremenchuk, A.S. Makarenko Pedagogical College

Country: Ukraine

Email: kramart@ukr.net

CHILDREN'S CREATIVITY OF PRESCHOOL AGE: CONCEPTNESS ANALYSIS

The article reveals the problem of formation of creativity from the preschool age, which is the most favorable for physiological and psychological indicators for the development of this psychological quality. The concept of person's "creation" and "creativity" are analyzed. The physiological features of child's brain activity of preschool age and the typology of thinking in the process of creativity formation are revealed.

Modernity presents new challenges and challenges in all spheres of social, professional and personal life, forcing them to refuse the usual patterns of thinking in solving various problems. Education is not an exception, but an advanced link that should professionally respond quickly to these challenges. This is the meaning of its existence and development. Intellectual production dominates the modern world, one of the main types of intellectual property has become intellectual, and the main driver of progress is creative ideas and technologies. The World Economic Forum in 2016 published "The Future of Jobs" report, which identified the relevant competencies of the person to be developed by 2020 to have good professional prospects in the future. One of the main - creativity (http://www3.weforum.org/docs/WEF_Future_of_Jobs.pdf).

Many foreign and domestic psychologists, among them; VI Barco, VN Druzhinin, VO Molyako, AM Tjutjunykov, T. Chervonna make the conclusion that creativity - personal quality, based on the development of higher mental functions. Moreover, the "primary" general creativity - the general ability to creativity develops at the age of 6-7 years under the influence of favorable environmental factors.

Domestic scientists of the preschool educational branch, headed by N.V. Gavrish attributes creativity to the basic personal qualities of a preschooler and characterizes it as "the intellectual quality of the personality, manifested in the propensity to creativity, the desire to move away from the pattern, pattern, as well as the ability to find original solutions, to rejoice in creating a new one" (N. Havrysh, p.88).

Preschool age is the time of tectonic movements in the psyche. A child with curiosity absorbs new concepts, impressions and experiences. It is at this age that there is sensory (sensory) development, the first attempts of creative approach to solving various problems. We believe that the formation of the creativity of preschool children is, first of all, a change in the logic of education and training, which moves towards a more individualized direction, when the process of children's improvisation is valuable in itself and leads to the development of innovative thinking, analytical skills, ability to work in a team that qualitatively influences readiness for future life and even civilizational challenges. Creativity is, in essence, not a knowledge or scientific activity, but a skill that can be improved qualitatively with the help of the latest, relevant opportunities, starting with the most successful for this according to the psychological and physiological indicators of the child's preschool age.

Key words: creation; creativity; imagination; creative potentia; improvisational type of thinking; artistic and game material.

Одержано 04.09.2019.

УДК: 613

DOI: https://doi.org/10.33989/2524-2474.2019.74.196631

\title{
ТЕТЯНА ПАРФІНЕНКО
}

ORCID: 0000-0001-7442-9027

(Харків)

Place of work: V. N. Karazin Kharkiv National University

Country: Ukraine

Email:t.parfunenko@karazin.ua

\section{ОСНОВНІ ПІДХОДИ ДО ВИЗНАЧЕННЯ ПОКАЗНИКІВ ЗДОРОВОГО СТИЛЮ ЖИТТЯ}

Стаття присвячена дослідженню основних підходів до визначення показників здорового стилю життя особистості. У процесі дослідження було встановлено взаємозв'язок між стилем та здоровим стилем життя і виділено їх спільні характеристики. 3 точки зору філософського підходу з'ясовано, що здоровий стиль життя являє собою специфічне утворення, яке виникає на підставі взаємодії між сутнісними силами людини, стильовими закономірностями та продуктом творчості особистості, тобто її здоров'ям. 
В публікації було зазначено про існування великої кількості трактувань щодо сутності поняття «здоров'я». Це дало можливість проаналізувати їх і згрупувати за принципом найбільш узагальнених характеристик зазначеної категорії. Уточнено розбіжності між «здоровим стилем життя» та «здоровим способом життя». Розглянуто найголовніші положення та ключові аспекти теорій А. Адлера, Г. Олпорта, М. Вебера та ін. науковців, які займались вивченням понять «стиль» та «стиль життя». У контексті цих напрацювань конкретизовано сучасні підходи до розуміння здорового стилю життя, як наукової категорії.

В процесі дослідження проаналізовано різні підходи до становлення категорії «здоровий стиль життя». В результаті цього було зроблено припущення, що вона скоріш підпадає під означення норми як ідеалу, аніж норми як зразка поведінки. Таким чином, здоровий стиль життя, можна дійсно вважати ідеальною формою поведінки, до якої прагне особистість, а не її зразком, який є тільки прикладом для наслідування.

У роботі сформульовано основні підходи та показники здорового стилю життя, до яких можна віднести: змістовно-цільовий, мотиваційно-ціннісний, індивідуально-орієнтований та соціально-показовий. Розглянуті підходи до визначення основних показників щодо здорового стилю життя дозволяють зробити висновок, що здоровий стиль життя є особистісною життєвою стратегією людини, що відображається у повсякденних практиках спрямованих на збереження і зміцнення здоров'я і допомагає зберегти високий рівень рефлексії у довгостроковій перспективі.

Ключові слова: здоров'я; особистість; стиль; здоровий стиль життя; вибір; індивідуальність; показники.

Постановка проблеми в загальному вигляді. Останнім часом, все частіше можна помітити зростаючий інтерес суспільства та науковців до проблематики здорового стилю життя. Передусім, це зумовлено існуванням багатомірної системи характеристик життєдіяльності людини, яка породжує велику кількість різноманітних стилів життя. Така ситуація призводить до появи нових життєвих стилів, які повинні відповідати сучасним викликам суспільства. Проте, слід зазначити, що утворення усіляких стилів життя не завжди $є$ корисним для здоров’я, а іноді і в загалі наносить велику шкоду.

Дослідженням стильової проблематики займались науковці з різних галузей науки. Найвагоміших здобутків у даній царині було досягнуто соціологією, філософією, психологією, педагогікою. Так, в соціології, стиль визначається, як більш зовнішня сторона особистості, тобто їі діяльність, місце, статус та положення у суспільстві. Філософська позиція щодо стилю розкриває вміння прийти до розуміння явища або предмета в його цілісності, єдності і взаємного зв'язку між його частинами. У психологічній науці поняттю «стиль» також надається велике значення, у більшості випадках його характеризують як індивідуальність в динаміці. В сучасних педагогічних дослідженнях поняття «стиль» з'являється в контексті розкриття потенціалу особистості, пізнання людиною самої себе, своїх можливостей, здатностей, особливостей і орієнтує особистість на створення власного здорового стилю життя. Це надає можливість особистості сконструювати індивідуальний здоровий стиль життя відповідно до типологічних особливостей та умовам життєдіяльності і без шкоди для здоров'я. Не зважаючи на це, проблематика здорового стилю життя не має чіткого окреслення у науково-педагогічному дискурсі, що диктує необхідність висвітлення різних підходів до визначення показників зазначеної категорії.

Аналіз останніх досліджень і публікацій. Розуміння здорового стилю життя у сучасній психолого-педагогічній літературі є досить новим, хоча дана категоріє дуже широко використовується у науковому обігу.

Проблема здорового стилю життя розглядалась у працях: С. О. Авчінникової, Д. Л. Бєлєнова, М. Я. Віленського, Ю. І. Євсєєва, В. О. Ліщука, А. Ф. Родіонова, Є. О. Уварова та ін. Проте, зміст та показники здорового стилю життя визначені не повністю.

Мета статті - визначити основні підходи до показників здорового стилю життя.

Виклад основного матеріалу дослідження. Вивчаючи основні підходи до визначення показників здорового стилю життя, необхідно спочатку розглянути природу походження такої категорії як «стиль».

Поняття «стиль» досить різноманітне і багатогранне, але не безмежне. Про стиль можна говорити коли маємо на увазі одяг, працю, мислення та ін., проте ніколи не скажемо про явища природи чи відносно тварин. Це свідчить про те, що поняття «стиль» вживається стосовно людської діяльності і описується у двох аспектах. По-перше, як діяльність, яка може розглядатися з точки зору характеристики способу їі здійснення, наприклад, стиль керівника чи стиль мислення. По-друге, стиль $€$ важливою характеристикою продукту діяльності.

Російський дослідник М. Віленський зазначає, що поняття «стиль» пов'язане з широким спектром характеристик індивідуальності людини. Він розглядає його як міждисциплінарне і розуміє під ним «...стійку цілісну, характерну єдність, систему прийомів і засобів діяльності, або характеристику продукту творчості, або своєрідне самовиявлення особистості суб'єкта діяльності» (Виленский, \& Авчинникова, 2004, с. 3). Причому стильову єдність усіх компонентів завжди можна чітко прослідкувати у діяльності за допомогою сприйняття, втілюючи стійку цілісність способу діяльності у типову форму її зовнішнього вираження. Такий досить абстрактний підхід до розуміння стилю дозволяє дуже легко знайти принципову спільність у дослідженнях проблем стилю представниками різних наукових дисциплін.

Цікавим, на нашу думку $є$ підхід до визначення стилю в одного із основоположників теоретичного мистецтвознавства німецького науковця Г. Вельфліна (Вельфлин, 1930). У його роботах історія мистецтва по суті стає історією стилю, а стиль виступає виключно характеристикою художньої форми. Г. Вельфлін у своїх дослідженнях повністю ігнорує індивідуальність митця і підкреслює тільки форму, тобто зорове 
сприйняття світу, явищ, предметів. Він це пов'язує з тим, що в процесі еволюції людського бачення на навколишній світ, у наслідок розвитку психічної природи людини, виникає і зміна стилів.

На противагу такої думки, з'являється зовсім діаметрально протилежна позиція ряду авторів (Тимо$\phi \epsilon є в, 1966 ;$ Ковалев, 1965). Вони вказують на те, що у розумінні стилю крім форми, яка тільки підкреслює зовнішній вираз, найбільш важливим є зміст продукту, а саме індивідуальність митця, яка має своє зображення у готовому витвору мистецтва.

Дослідження зазначеної проблеми показало також і існування третьої точки зору, згідно з якою поняття «стиль» окреслюється не просто як форма або набір елементів чи зміст, а як певний момент їхньої взаємодії, тим самим підкреслюючи взаємозалежність форми та змісту (Соколов, 1968). Такий підхід до визначення стилю, вважається найбільш ефективним.

Проаналізувавши вищевикладений матеріал, можна стверджувати, що категорії «стиль» та «форма» дуже схожі між собою і мають спільні характеристика, такі як стійкість, цілісність та єдність. Проте зазначені характеристики не є системоутворюючими. Принципово важливу роль при визначенні специфіки стильової єдності набуває вирішення питання щодо природи стильової спільності. При цьому джерело формування стильових закономірностей відокремлюється від предмета, стиль розглядається як своєрідне вираження сутнісних сил суб'єкта в процесі або результаті діяльності і тільки тоді стає можливим реально уявити, який аспект взаємозв'язку змісту та форми входить до поняття «стиль» (Ануфрієва, Головаха, \& Донченко, 1982).

У контексті пропонованого дослідження під джерелом стильових закономірностей розуміється система ознак, які характеризують зовнішні прояви стилю, під сутнісними силами людини - сукупність інтелекту, почуттів людини та її волі, які в цілому дозволяють розвивати здібності, що в свою чергу обумовлені розвитком потреб, а під продуктом діяльності - здоров'я. Взаємозв'язок між цими трьома складовими і утворює здоровий стиль життя.

Аналіз наукової літератури свідчить про існування понад 450 визначень здоров'я людини, сформульованих фахівцями з різних наукових дисциплін. Можна відмітити шість основних типів сутнісних елементів визначення здоров'я: 1) здоров'я, як норма функціонування організму на всіх рівнях його організації; 2) здоров'я, як динамічна рівновага (гармонія) життєвих функцій організму; 3) здоров'я як повноцінне виконання основних соціальних функцій, участь у житті суспільства й активна трудова діяльність; 4) здатність організму адаптуватися до умов навколишнього середовища, що змінюється; 5) відсутність патологічних змін і нормальне самопочуття; 6) повне фізичне, духовне, розумове й соціальне благополуччя (Бойчук, 2017).

Нерідко у науковій літературі можна зустріти ототожнення здорового стилю життя зі здоровим способом життя, проте ці дві категорії мають відмінності між собою. Здоровий спосіб життя вважається дотриманням норм або правил чи приписів, які сприяють збереженню та зміцненню здоров'я. Водночас, характерною ознакою для здорового стилю життя виступає індивідуальність особистості, з урахуванням якої робиться вибір певного способу життя. Здоровий стиль життя, на відміну від здорового способу життя, $\epsilon$ набагато вужче і формується навколо певної особистості.

Як зазначалось вище, здоровий стиль життя, як і стиль - є поняттям, що характеризує людську діяльність зі специфічної позиції й містить два аспекти: 1) як процес виконання будь-якої діяльності, наприклад, виконання фізичних вправ, використання методик, що відновлюють здоров'я та ін. 2) як продукт або результат діяльності: добре самопочуття, гарна фізична форма та ін.

Аналіз сучасних досліджень засвідчив, що у суспільстві спостерігається тенденція до появи нових стилів життя, яку пов'язують з розвитком консьюмерізації, гедонізації, інформатизації, віртуалізації, приватизації і публіцізації життя, просторової та професійної мобільності (Шульга, 2011). В суспільстві відбувається нав'язування певного стилю життя, який є популярним і модним. У зв' язку з цим, можливість самостійно вибору особистістю форми життєвої поведінки, яка буде відповідати іï внутрішньому світу (світогляд, ціннісно-нормативна сфера, установки та ін.), вкрай обмежена. Проте, за словами Іоніна Л., (Ионин, 2000) «стиль присутній виключно там, де є вибір». Відповідно, стиль життя - це типовий вибір в рамках можливого, який повинен бути зроблений свідомо. В іншому разі це буде не стиль, а тимчасово нав'язаний тип поведінки зовні. Таким чином, фактично ми говоримо про здоровий стиль життя як про індивідуальний «запит на здоров'я» особистості, який передбачає високий рівень свідомості та відповідальності, а також постійний щоденний вибір і боротьбу із двома базовими невротичними одержимостями людства - лінню та страхом.

Здоровий стиль життя та індивідуальні властивості особистості, на нашу дуку, є взаємозалежними і можуть визначатися, як наявністю індивідуального у здоровому стилі життя, так і наявністю здорового стилю життя в індивідуальності. Таким чином, при виборі здорового стилю життя необхідно враховувати індивідуальні особливості людини, такі як характер, темперамент, схильності, здібності, біоритми, харчування тощо. I навпаки, здоровий стиль життя робить людину особистістю, додаючи їй індивідуальних рис характеру та підкреслюючи ії неповторність.

Вивчаючи категорію «здоровий стиль життя», можна побачити більш її практичну, ніж теоретичну їі спрямованість. Реалізація здорового стилю життя полягає у повсякденному використанні здорових практик, таких як: фізичні вправи, ціннісні орієнтації, позитивне мислення, раціональне харчування, співвідношення праці та відпочинку, сну та рухової активності, які з часом перетворюються у звички. Звісно, що звички можна сформувати приблизно протягом трьох тижнів, хоча у деяких випадках може знадобиться й більше часу. Звичка - це стереотипний спосіб поведінки, яка в певній ситуації набуває характеру потреби. Вона грунтується на комплексі умовно-рефлекторних реакцій і має психологічний компонент. ІЇ̈ реалізація приносить позитивні емоції, а неможливість реалізації - негативні. Така потреба пов'язана з утворенням у мозку стійких нервових зв'язків, про які писали ще Іван Павлов і Микола Бернштейн. Таким чином, щоденне 
виконання здорових практик, призводить до формування потреби у здоровому стилі життя, яка з часом стане невіддільною частиною життя особистості.

Суттєвий внесок у дослідження стилю життя зробив австрійський психолог А. Адлер. У своїх дослідженнях він зазначав, що людина не є пасивним об'єктом впливу навколишнього середовища, а у боротьбі за своє місце у житті сама активно впливає на навколишній світ, тобто є творцем свого життя.

Такий підхід буде доцільним і при конструюванні здорового стилю життя особистості. Так, наприклад, якщо людина має якісь недоліки або надмірну вагу чи незадовільна своєю фізичною формою, то вона починає експериментувати, вироблювати нову тактику своєї поведінки щоб компенсувати відчуття неповноцінності. У зв'язку з цим, з'являються якості, які до цього часу були невідомі людині й спонукають її до внутрішніх трансформацій, тобто до самоствердження та самовдосконалення. Зазначені перетворювання стають у подальшому житті особистості ядром її здорового стилю життя.

Класичними для розробки здорового стилю життя стали роботи Г. Олпорта щодо мотиваційних та інструментальних рис особистості. Для того щоб здоровий стиль життя став кінцевим результатом необхідно зробити мотив драйвером, бажанням особистості щось змінити і чогось досягти. Г. Олпорт називає такі риси «мотиваційними», а за рахунок чого і яким способом це можна зробити - це «інструментальні» риси». Тобто, щоб змінити своє життя необхідно діяти. У даному випадку, діяльність повинна бути не спонтанною, а осмисленою, підкріпленою знаннями, спрямованою на налагоджування здорових стосунків між людьми, тобто мати психологічну основу. Таким чином, здоровий стиль життя є нібито таким містком, який з'єднує внутрішній світ особистості з її вчинками, діями та поведінкою воєдино.

Згідно з концепцією М. Вебера щодо розподілу суспільства на групи відповідно їх стилю життя, здоровий стиль теж має здатність об'єднувати людей в окрему групу, які мають зацікавленість у збереженні й зміцненні здоров'я і, тим самим, наділяє їх певними відмінностями від інших. Таким чином, така спільнота має престижний статус у суспільстві й відрізняється гарною фізичною формою, позитивним настроєм, енергійністю, бадьорістю та життєрадісністю.

Здоровий стиль життя безпосередньо пов'язаний з дозвіллям особистості, а скоріше за все з його організацію. Від того як людина проводить вільний час залежить їі фізичний та духовний відпочинок. Позитивні враження, спілкування з друзями, родиною, активність, відкриття чогось нового - все це наповнює і заряджає енергією, незабутніми емоціями, що надихають людину на подальше творення свого життя. I навпаки, час об'єктивно спрямований на психологічне і моральне самознищення: примітивізм міжособистісних відносин, чвари, пияцтво - знищую людину як особистість та породжує злість, ненависть, заздріть. Отже, правильна організація дозвілля, є необхідною умовою здорового стилю життя, що полягає у доцільності відпочинку, який приносить користь особистості і сприяє зміцненню її здоров’я.

Проаналізувавши різні підходи до становлення категорії «здоровий стиль життя» ми побачили, що вона скоріш підпадає під означення норми як ідеалу, аніж норми як зразка поведінки. Таким чином, здоровий стиль життя, можна дійсно вважати ідеальною формою поведінки, до якої прагне особистість, а не її зразком, який є тільки прикладом для наслідування.

Вивчення наукової літератури показало існування великої кількості підходів, положень та концепцій до становлення здорового стилю життя, які віддзеркалюють багатогранність проявів людської сутності, а саме повсякденну поведінку, активність, відпочинок, мотивацію, цінності, індивідуальні особливості, групу людей об'єднаних спільною ідеєю та ін.. Це стало підставою для виділення основних показників здорового стилю життя, які відбивають його специфіку і унікальність. До них можна віднести наступні: змістовноцільовий (стиль поведінки; стиль спілкування; стиль діяльності (основний); активність особистості), мотиваційно-ціннісний (основні мотиви, цілі, сенс, принципи, життя; позиція в житті; відносини до людей, діяльності, своєї особистості; орієнтація на культурні ціннісні), індивідуально-орієнтований (вікові особливості; біоритми; соціальні ритми (повторюваність діяльності в різних аспектах, повторюваність дій в кожній зі сфер перебування); темперамент, характер, здібності.) та соціально-показовий (соціальні ролі; соціальний статус; віково-рольові очікування (відставання або випередження); авторитет в групі; престиж.). Дані показники, можна вважати узагальненою структурою здорового стилю життя.

Висновки з даного дослідження і перспективи подальших розвідок Отже, в процесі дослідження було означено основні показники, які розкривають сутність і зміст здорового стилю життя, крізь основні аспекти: поведінковий, внутрішнього світу, індивідуальний і соціальний. Такий підхід до здорового стилю життя як особистісної життєвої стратегії, яка відбивається у повсякденних практиках спрямованих на збереження і зміцнення здоров'я дозволяє зберегти високий рівень рефлексії у довгостроковій перспективі.

До перспективної тематики подальших наукових досліджень можна віднести питання, що пов'язані 3 розробкою індивідуальної програми здорового стилю життя особистості.

\section{СПИСОК ВИКОРИСТАНОЇ ЛІТЕРАТУРИ}

Ануфриева Р. А., Головаха Е. И., Донченко Е. А. Стиль жизни личности. Теоретические и методологические проблемы. Киев : Наук. думка, 1982. 372 с.

Бойчук Ю. Д. Сучасні підходи до розуміння сутності здоров’я людини та суміжних з ним понять. Загальна теорія здоров'я та здоров'язбереження / ред. Ю. Д. Бойчук. Харків : Вид. Рожко С. Г., 2017. C. 5-16. URL: http://hnpu.edu.ua/sites/default/files/files /Kaf_zdor_ta_korr_os/Zagalna_teorija_zdorovia_i_zdorviazberegennja.pdf

Вельфлин Г. Основные понятия истории искусства. Москва, 1930. С.145.

Виленский М. Я., Авчинникова С. О. Методологический анализ общего и особенного в понятиях «здоровый образ жизни» и «здоровый стиль жизни». Теория и практика физической культуры. 2004. № 11. С. 2-7. 
Ионин Л. Социология культуры: путь в новое тысячелетие. Москва : Логос, 2000. 431 с.

Ковалев В. А. Многообразие стилей в советской литературе. Москва ; Ленинград, 1965. 140 с.

Соколов А. Н. Теория стиля. Москва : Искусство, 1968. 224 с

Тимофеев Л. И. Основы теории литературы. 3-е изд. Москва : Просвещение, 1966. 320 с.

Шульга Н. А. Новейшие тенденции в развитии современных стилей жизни. 2011. URL: https://lib.sale/politicheskaya-filosofiya-knigi/noveyshie-tendentsii-razvitii-sovremennyih-59700.html

\section{REFERENCES}

Anufrieva, R. A., Golovakha, E. I., \& Donchenko, E. A. (1982). Stil' zhizni lichnosti. Teoreticheskie i metodologicheskie problem [Personality lifestyle. Theoretical and methodological problems]. Kiev: Nauk. dumka [in Russian].

Boichuk, Yu. D. (2017). Suchasni pidkhody do rozuminnia sutnosti zdorov'ia liudyny ta sumizhnykh z nym poniat [Modern approaches to understanding the essence of human health and related concepts]. In Yu. D. Boichuk(Ed). Zahalna teoriia zdorov'ía ta zdorov'iazberezhennia [General Theory of Health and Health Conservation] (pp. 5-16). Kharkiv: Vyd. Rozhko S. H. Retrieved from http://hnpu.edu.ua/sites/default/files/files /Kaf_zdor_ta_korr_os /Zagalna_teorija_zdorovia_i_zdorviazberegennja.pdf [in Ukrainian].

Ionin, L. (2000). Sotsiologiya kul'tury: put'v novoe tysyacheletie. Moskva: Logos [in Russian]. Kovalev, V. A. (1965). Mnogoobrazie stilei v sovetskoi literature [The variety of styles in Soviet literature]. Moskva; Leningrad [in Russian].

Shul'ga, N. A. (2011). Noveishie tendentsii v razvitii sovremennykh stilei zhizni [The latest trends in the development of modern lifestyles]. Retrieved from https://lib.sale/politicheskaya-filosofiya-knigi/noveyshie-tendentsii-razvitii-sovremennyih59700.html [in Russian].

Sokolov, A. N. (1968). Teoriya stilya. Moskva: Iskusstvo [in Russian].

Timofeev, L. I. (1966). Osnovy teorii literatury [Fundamentals of Literature Theory]. Moskva: Prosveshchenie [in Russian].

Vel'flin, G. (1930). Osnovnye ponyatiya istorii iskusstva . Moskva [in Russian]. Vilenskii, M. Ya., \& Avchinnikova, S. 0. (2004).

Metodologicheskii analiz obshchego i osobennogo v ponyatiyakh «zdorovyi obrazzhizni» i «zdorovyi stil'

zhizni» [Methodological analysis of the general and the special in the concepts of "healthy way of life" and "healthy

lifestyle"]. Theory and Practice of Physical Culture, 11, 2-7 [in Russian].

PARFINENKO TETIANA

Place of work: V. N. Karazin Kharkiv National University

Country: Ukraine

Email:t.parfunenko@karazin.ua

\section{BASIC APPROACHES TO DETERMINING HEALTHY LIFESTYLE INDICATORS}

The article is devoted to the study of the main approaches to determining healthy lifestyle indicators of an individual. The study identified the relationship between a style and healthy lifestyle and highlighted their common characteristics. From the perspective of the philosophical approach, it has been found out that a healthy lifestyle is a specific formation that arises on the basis of the interaction between the essential forces of the person, stylistic patterns and the product of the creativity of the individual, that is, their health. The publication noted the existence of a large number of interpretations of the essence of the concept of "health". This made it possible to analyze and group them according to the principle of the most general characteristics of the specified category. The differences between a "healthy lifestyle" and "healthy way of life" have been clarified. The main positions and key aspects of the theories of A. Adler, G. Allport, M. Weber and other scientists, who studied the concepts of "style" and "lifestyle" have been considered. In the context of these developments, modern approaches to understanding healthy lifestyle as a scientific category have been specified.

In the course of the research various approaches to establishment of a "healthy lifestyle" category have been analyzed. As a result, it was assumed that it falls within the definition of a norm as an ideal rather than a norm as a pattern of behavior. Thus, a healthy lifestyle can, indeed, be considered an ideal form of behavior that the individual strives for, not the role model, which is only an example to follow.

The paper formulates the basic approaches and indicators of a healthy lifestyle, which can be attributed: content-targeted, motivational-value, individually-oriented and socially-demonstrative. The approaches to the definition of key indicators of a healthy lifestyle suggest that a healthy lifestyle is a person's life strategy, reflected in everyday practices aimed at maintaining and promoting health and helping to maintain a high level of reflection in the long term.

Keywords: health; individual; style; healthy lifestyle; choice; individuality; indicators.

Одержано 02.09.2019

УДК 373.2.015.31:17

DOI: https://doi.org/10.33989/2524-2474.2019.74.196633

ОКСАНА СТАНІЧЕНКО

ORCID: 0000-0002-4816-6718

(Полтава)

Place of study: Poltava V.G. Korolenko National Pedagogical University

Country: Ukraine

Email: ksuskaa1982@gmail.com

\section{ВЗАЄМОДІЯ ЗАКЛАДІВ ДОШКІЛЬНОЇ ОСВІТИ З РОДИНАМИ У ВИХОВАННІ ЧУЙНОСТІ}

У статті наголошується на необхідності виховання чуйності у дітей дошкільного віку, як базової якості особистості, яка виявляється в турботі про потреби, запити й бажання оточуючих, уважності до їхніх інтересів, проблем, співчуття до навколишніх, готовності прийти на допомогу. 